Trab. Ling. Aplic., Campinas, 43 (2): 323-344, Jul./Dez. 2004

\title{
CORREÇÃO DE TEXTO: UM DESAFIO PARA O PROFESSOR DE PORTUGUÊS
}

\author{
RUTE IZABEL SIMÕES CONCEIÇÃO \\ (Universidade Federal de Mato Grosso do Sul)
}

\begin{abstract}
This article presents the results of a study involving a group of teachers of Portuguese enrolled in a special course for continuing education offered at the campus of Dourados of the Federal University of the State of Mato Grosso do Sul, Brazil (UFMS). The research investigated the relationship between the classroom practices of the teachers and the methodology advocated in the course of Methodology of Text Production, especially in relation to the dialogue between writing / rewriting and the correction of texts. The results identify some of the issues involved in the teaching of text production which are of special concern to these teachers during daily classroom activities. These were reflected in the conflicts revealed by the subjects about classroom teaching when they were challenged not only to act and interact but to reflect on their own history of teaching and learning in relation to text production.
\end{abstract}

Keys-world: correction of texts, writing teaching-learning, mother tongue.

\section{INTRODUÇÃO}

Uma das maiores dificuldades dos professores de Língua Portuguesa está no ensino da produção textual, mais especificamente, no momento da correção. Como corrigir? O que corrigir? Para que corrigir? Essas são perguntas que os professores fazem, especialmente por se sentirem impotentes diante dos minguados progressos na qualidade das produções escritas pelos seus alunos, conforme afirma a professora em seu texto de avaliação da disciplina Metodologia da Produção Textual ${ }^{1}$ :

Foi muito proveitoso para mim o curso de Metodologia do Ensino da Produção Textual. Achava mesmo que alguma coisa precisava ser feita para que os alunos pudessem reescrever seus textos de forma que melhorassem o conteúdo do mesmo e não apenas a forma, como sempre foi feita, com uma correção presa ao apontamento dos erros de acentuação, ortografia e concordância. Eu, pessoalmente, não sabia como fazer meus alunos melhorarem seus textos, o que era muito frustrante (Avaliação final $-A 2^{2}$ ).

\footnotetext{
${ }^{1}$ Disciplina ministrada no Curso de Especialização em Língua Portuguesa oferecido pela UFMS/Campus de Dourados em 2001 e 2002.

${ }^{2}$ Cada informante recebeu uma letra e um número identificadores.
} 
Pretendemos, neste artigo, discutir algumas possibilidades de ação docente na orientação do processo de ensino de produção textual, especialmente no que se refere à correção do texto do aluno. Para isso, refletiremos sobre a literatura que trata da questão, mais especificamente em Maria Tereza Serafini (1994) e Eliane Ruiz (1998) e, também, sobre as ações didáticas realizadas na disciplina Metodologia da Produção Textual e as reações dos professores no que se refere à escrita, reescrita, publicação e correção de textos.

\section{CORREÇÃO: DEFINIÇÃO E TIPOS}

Na literatura, um dos trabalhos de referência sobre correção de texto é o realizado por Serafini (1994). Em seu livro, no capítulo 7 (sete), trata especificamente do tema. A autora define essa tarefa como sendo o conjunto de intervenções que o professor faz, prioritariamente, para apontar defeitos e erros e, secundariamente, para avaliar.

Sentimos a necessidade de acrescentar a essa definição o aspecto construtivo e interativo que deve ter a correção, isto é, aquilo que pressupõe ao professor uma postura mais distante do juiz, do avaliador e mais próxima do interlocutor que está disposto a dialogar com o texto e seu autor. Acreditamos que o professor terá um retorno mais positivo se assumir uma postura construtiva e interativa na correção, tendo em vista que o aluno deixará de considerar a escrita do texto ${ }^{3}$ como tarefa escolar que se cumpre ao entregar a versão única e definitiva ao professor.

Considerando isso, propomos que uma definição de correção (e sua prática também) deva contemplar a perspectiva de proporcionar a autonomia ao aluno para analisar o próprio discurso ${ }^{4}$. Para isso, faz-se necessário que a prática da correção leve de fato o aluno à reflexão sobre seu próprio discurso e sobre os possíveis efeitos de sentido que seu dizer produzirá no interlocutor. Aceitar isso significa aceitar que o texto produzido em situação escolar extrapole os limites da "redação escolar" (vista como tarefa escolar) e seja compreendido como uma unidade significativa de interlocução à distância que produz conhecimento.

Um outro aspecto da correção abordado por Serafini (1994) é o que trata dos tipos de correção. Pretendemos, além dos três tipos apontados, discutir um outro tipo que pesquisas mais recentes já classificaram.

No que se refere aos tipos de correção, a autora afirma ${ }^{5}$ que a maioria dos professores oscila entre dois tipos, a resolutiva e a indicativa. Afirma, ainda, que há um terceiro tipo muito raramente utilizado pelos professores, a correção classificatória.

A correção resolutiva consiste em corrigir todos os erros encontrados no texto reescrevendo palavras, frases e períodos inteiros. Nesse caso, a solução do erro reflete

${ }^{3}$ Entende-se por texto escrito, neste trabalho, a atividade discursiva escrita que forma um todo significativo, com objetivo de interagir com algum interlocutor à distância.

${ }^{4}$ Discurso, aqui, está sendo entendido como atividade lingüística em que se diz alguma coisa a alguém, de uma determinada forma, num determinado contexto histórico e em determinadas circunstâncias que influem as escolhas feitas ao produzir tal discurso.

${ }^{5}$ Faz isso citando Aplebee (1981). 
apenas a opinião do professor, já que seu discurso se sobrepõe ao do aluno, evidenciando uma postura autoritária, fortemente assimétrica.

A correção indicativa consiste em marcar junto à margem palavras, frases e períodos inteiros que apresentam erros ou são pouco claros. O professor se limita à indicação do erro e altera muito pouco o texto, limitando-se a erros localizados. Para Serafini (op. cit.), esse tipo de correção não leva o aluno à solução dos problemas do seu texto, especialmente porque o erro não vem apontado com precisão ${ }^{6}$. Concordando com Serafini sobre os efeitos desse tipo de correção, Brumatti (1999), em pesquisa mais recente, constatou na clientela pesquisada que esse foi o tipo de correção mais utilizado.

Para Ruiz (1998), embora problemático no que se refere à intenção de levar o aluno a identificar e corrigir os problemas no seu texto, esse tipo de correção pode ser considerado menos problemático que a correção resolutiva. Ponto de vista que será discutido mais adiante.

Quanto à correção classificatória, esta consiste na identificação não-ambígua dos erros através de uma classificação. Para Serafini, esta é uma correção que respeita os princípios de uma boa correção porque prevalece uma atitude operativa (identifica-se o erro, especificando a operação que o aluno errou), enquanto nas outras duas prevalece uma atitude prescritiva (indica-se ou resolve-se o erro).

Temos constatado, através dos relatos de professores participantes de cursos por nós ministrados, que os professores ao procurarem utilizar uma correção classificatória e ao terem que assumir a tarefa de fazer uma classificação dos problemas, fazem-no, prioritariamente, do ponto de vista formal.

Nesses casos, embora a correção classificatória respeite os princípios de uma boa correção, como afirma Serafini, se esta ficar presa à classificação dos problemas gramaticais, não tocará, nem de longe, no real problema do texto do aluno. Conseqüentemente, o discurso do aluno vai sendo desconstruído pela escola ao longo da escolarização. O resultado prático disso, na maioria dos casos, é que quanto mais adiantado é o grau de escolarização, maior é o silenciamento do aluno e sua conseqüente opção pela repetição de estereótipos e expressões que denotam o lugar-comum (Cf. Pécora, 1992; Costa Val, 1993).

Quanto à correção dos problemas discursivos ${ }^{7}$, os professores alegam ser muito complexo classificá-los e, mais complexo, ainda, torna-se encaminhar as orientações de forma organizada, de maneira que o aluno consiga resolver os problemas do seu texto/ discurso. Em decorrência disso, centram a correção nos aspectos mais superficiais do texto.

Ruiz (1998), em sua tese de doutorado - Como se corrige redação na escola -, ao analisar textos corrigidos por diversos professores, além de constatar a presença dos três tipos abordados por Serafini (1994), apontou e descreveu a presença de mais um tipo de correção que denominou de textual-interativa. Essa correção, segundo ela, corresponde a comentários mais longos escritos após o texto do aluno e se realiza em forma de bilhetes que tratam da tarefa de revisão pelo aluno ou da tarefa de correção do professor. Segundo

\footnotetext{
${ }^{6}$ Há casos em que o professor apenas faz um risco vertical na margem do texto do aluno assinalando um grande trecho.

${ }^{7}$ Problemas discursivos, neste trabalho, correspondem aos problemas referentes aos aspectos pragmáticos e semântico-conceitual.
} 
Ruiz (op. cit.), a maioria absoluta das correções textuais-interativas são utilizadas para incentivar o trabalho de reescrita pelo aluno, elogiando o trabalho feito ou cobrando o que não foi feito.

Nesta investigação, foram consideradas correções textuais-interativas aquelas que apontavam os problemas discursivos presentes no texto, desafiavam os alunos a refletirem sobre seu discurso através de questionamentos, sem, no entanto, resolver o problema pelo aluno, de modo que este se sentisse orientado e encorajado a reescrever seu texto.

Diferente de Serafini (1994) e partindo do ponto de vista da Análise do Discurso, Ruiz (1998) agrupou as correções em monofônicas e polifônicas ${ }^{8}$ e concluiu em sua análise que não somente a correção classificatória, mas também a indicativa e a textual-interativa são polifônicas. Nessas, o professor pressupõe explicitamente a presença do outro em seu discurso, na medida em que se utiliza de uma metalinguagem (verbal ou icônica) que requer a participação efetiva do outro na construção das alterações a serem realizadas na reescrita. Quando a correção se dá na forma resolutiva, no entanto, o professor é monofônico, já que apresenta as alterações a serem aplicadas, sobrepondo, anulando com seu discurso a presença do outro (do aluno).

\section{A EXPERIÊNCIA E SUAS CONDIÇÕES DE PRODUÇÃO: OS DOIS LADOS DA MOEDA - O PROFESSOR-ALUNO-PROFESSOR E A (RE)CONSTRUÇÃO DE UM SABER/FAZER}

Inicialmente, quando ainda se planejava a disciplina Metodologia da Produção Textual, sabia-se que teria 45 horas de duração e seria oferecida em um período concentrado ( 5 encontros ${ }^{9}$ de 8 horas e 5 horas para leituras e refacção textual). A clientela ${ }^{10}$ seria composta por onze professores das redes pública e particular de ensino, todos formados há pelo menos três anos em Letras. Alguns deles já haviam concluído um curso de especialização.

Dentre as questões da sondagem que eles responderam antes de iniciar a disciplina Metodologia da Produção Textual, uma delas - Você está satisfeita(o) com o trabalho de produção textual que vem realizando com seus alunos? Por quê? Isto é, seus alunos estão melhorando a qualidade da escrita? - foi determinante para a decisão dos objetivos que norteariam o trabalho a ser realizado na disciplina, considerando que se mostraram insatisfeitos com o ensino de produção textual que estavam realizando, como se pode constatar através dos seguintes registros:

\footnotetext{
${ }^{8}$ O sentido empregado é o estabelecido por Bakhtin (1995).

${ }^{9}$ Além dos cinco encontros previstos, ocorreram encontros para atendimento mais individualizado. Os encontros foram gravados em vídeo.

${ }^{10}$ No início do Curso, coletaram-se informações sobre a clientela através de um questionário de sondagem. Além desse, os seguintes instrumentos deram suporte às reflexões: gravação em vídeo das aulas e dos encontros para comentários dos textos; coleta dos textos escritos e reescritos pelos alunos, com as anotações escritas pelo professor; redação, pelos alunos, de um diário das aulas, de uma auto-avaliação e de um texto avaliando as aulas.
} 
Não. Porque meus alunos continuam escrevendo mal (Sondagem - M 1).

Não. [...], pois meus alunos não gostam de escrever (Sondagem - C 5).

Não, porque são bem poucos os que têm conseguido melhorar (Sondagem - A 7).

Com base nas informações obtidas no questionário de sondagem, definimos que o objetivo do trabalho na Disciplina seria o de oportunizar aqueles profissionais a refletirem criticamente sobre as ações didáticas com eles realizadas durante o Curso e sobre suas próprias ações didáticas no trabalho que desenvolviam nas escolas em que ensinavam a produzir textos.

Como informaram que trabalhavam com textos narrativos, descritivos e dissertativos decidimos que nas atividades em sala de aula seriam discutidas essas modalidades discursivas, e a relação que estabelecem entre si. Selecionado o conteúdo, seria necessário estabelecer a metodologia. O questionário de sondagem apontou para duas questões que seriam determinantes na decisão da metodologia a ser adotada:

1) embora o ensino da escrita do texto seja uma das tarefas do professor de Português, eles próprios geralmente não têm a prática de escrever:

... posso dizer, sem constrangimento, que fiquei muito feliz e sem sombra de dúvida estimulada a exercer esse papel de escritora que a vida se me apresenta. Parece-me que com esse exercício de reescrita que fizemos no Curso pude libertar-me de opressões que me impediam de exercer tal atividade, sempre me julgava incapaz. [...] foi a descoberta de algo valioso para minha profissão (Avaliação final da disciplina - 2001 - A 2).

2) discutir as questões pretendidas somente no plano teórico não produziria o mesmo efeito que discutir a partir da prática (para isso, seria preciso levá-los a escrever, analisar e reescrever seus próprios textos). Sobre isso, C 3 registrou:

\footnotetext{
Posso afirmar, sem medo de exageros que, desde o começo do Curso, esta foi a minha melhor oportunidade de trabalhar diretamente com idéias que modificam a minha atuação em sala de aula, frente aos meus alunos, [...] Eu diria que estou tão mais aliviada em descobrir que a tarefa de escrever pode ser muito mais interessante para os meus alunos, como é agora para mim. [...] Não conhecia os elementos essenciais de um texto como conheço agora, assim na prática.
}

Tomadas essas decisões e iniciada a Disciplina, desde o primeiro momento do Curso, refletiram sobre as ações da professora ministrante, as ações e reações deles próprios enquanto alunos e, também, sobre suas ações enquanto professores que ensinavam redação aos seus alunos. Esperávamos que, dessa forma, algumas verdades, algumas certezas que se repetem ano após ano nas salas de aula pudessem ser de-sedimentadas, pudessem ser desmascaradas e desconstruídas.

Foi um trabalho bastante complexo que mexeu não só com o intelecto, mas também com o emocional daqueles docentes que ora experimentavam o lugar de aluno (quando recebiam a tarefa de produzir o texto, de lê-lo para os colegas em sala, de entregá-lo para o professor fazer as observações, de reescrevê-lo etc.), ora experimentavam o lugar de professor (quando discutiam os procedimentos do professor ministrante na correção de seus textos, a concepção de língua/linguagem e de ensino subjacentes a esses procedimentos 
etc.). Os depoimentos seguintes dão uma idéia dos conflitos e das descobertas vividos por aqueles professores-alunos e denunciam que nem tudo foi tranqüilo e pacífico como geralmente ocorre nas salas de aula em geral: A sala estava inquieta, os colegas falavam sobre suas dificuldades. A \{...\} sentia-se incomodada. Para a [...] aquilo significava um grande desafio (Diário do dia 28/09/01 - C 3).

\begin{abstract}
Perante essa metodologia tive inúmeras dificuldades, desde a aceitação da reescrita até a interação entre eu, o texto e os colegas da sala. Houve um grande bloqueio.... Nos primeiros encontros eu me recusei a fazer a interação com os colegas, a ler meus textos... (Avaliação final - 2001 - A 1).
\end{abstract}

\title{
2.1. A correção e suas conseqüências no ensino de produção textual
}

Sabe-se que, para realizar uma correção que capacite o aluno a refletir sobre os problemas discursivos do seu texto, é necessário que o professor tenha claro para si e deixe claro aos seus alunos, desde o momento inicial da produção textual, os procedimentos básicos que nortearão o trabalho e determinarão a qualidade da interação professor x aluno $\mathrm{x}$ texto.

No trabalho realizado com os alunos do Curso de Especialização, os procedimentos seguintes foram determinantes durante o processo de produção/correção dos textos: Constituir-se, o professor, um interlocutor do texto do aluno; Estabelecer e hierarquizar os critérios e a forma de correção: como e o que corrigir; Negociar a forma de publicação do texto durante e após o processo de elaboração; Possibilitar a reescrita quantas vezes o aluno-autor julgar necessário.

Convém esclarecer que o que estaremos apresentando e discutindo a seguir não se constitui em uma receita, mas em procedimentos que fizeram parte das condições de produção durante uma experiência que está sendo objeto de estudo em uma pesquisa ${ }^{11}$ em desenvolvimento.

Em contexto escolar, as decisões sobre os procedimentos didáticos em sala de aula passam pelo professor que, consciente ou inconscientemente, é quem decide sobre os princípios norteadores do ensino que efetivará.

\subsubsection{Constituir-se, o professor, um interlocutor do texto do aluno}

Na perspectiva em que o trabalho foi desenvolvido, um professor que esteja ensinando a produção textual precisará deslocar-se da posição de avaliador, de juiz do texto do aluno para tornar-se um interlocutor de verdade - em sala de aula, o professor é um interlocutor privilegiado -, mostrando-se interessado no que o aluno tem a dizer, concordando, discordando, questionando, dialogando, enfim, com o texto e seu autor.

Se o professor não assumir verdadeiramente uma posição de interlocutor, dificilmente o aluno construirá a noção de interlocução à distância - característica básica que diferencia um texto oral de um texto escrito - nem mesmo se assumirá como sujeito do seu discurso;

\footnotetext{
${ }^{11}$ A pesquisa referida está sendo desenvolvida no Departamento de Comunicação e Expressão/Campus de Dourados/UFMS, sob o título "A (re)construção da discursividade na escrita".
} 
muito pelo contrário, utilizar-se-á, conforme pesquisas já têm constatado (cf. Pécora, 1992; Costa Val 1993; Guedes, 1994; Coracini, 1999; Conceição 2000a), da repetição de discursos prontos e acabados, que se constituem em colagem mal ajambrada ${ }^{12}$ nas redações escolares em geral.

Ao assumir a perspectiva de um interlocutor, espera-se que o professor interaja com o texto (e com seu autor) e cuide para que, ao sugerir as alterações ${ }^{13}$, com seu discurso, não anule a presença do outro (do aluno), silenciando-o.

Uma atitude interativa por parte do professor provavelmente levará o aluno a assumirse como sujeito do seu dizer, já que terá um interlocutor ${ }^{14}$ - que mostrará isso através das suas observações no/ao texto - interessado no que o aluno tem a dizer, incentivando-o a refletir sobre o que dizer e a melhor forma de dizer aquilo que pretende ao seu leitor, em vez de ter uma função-professor cobrando apenas o cumprimento de uma tarefa.

$\mathrm{Na}$ experiência em estudo, a reação a essa interação parece ter sido positiva como deixa transparecer o registro seguinte: É interessante ouvir as leituras dos textos e os comentários da professora nos chamando a atenção para elementos que antes nem percebíamos. [...] e ficávamos incapacitados de sair do superficial (Diário do dia 21/09/ $01-\mathrm{A} 2)$.

Um aspecto que se mostrou relevante nesse tipo de interação (menos assimétrica) estabelecida, em que o professor procurou assumir uma postura de interlocutor do texto do aluno em vez de juiz/avaliador, é que os alunos passaram também a assumir uma postura menos passiva, tornaram-se mais questionadores. Talvez por se sentirem desafiados a pensar sobre sua própria prática, as questões seguintes foram algumas das que mais inquietaram o grupo: O professor dialogará com o texto (e seu autor) a partir de quais princípios norteadores? Como decidirá sobre que aspectos anotará suas observações? Diante de inúmeros problemas encontrados nos textos dos alunos, com quais se preocupará primeiro? Tais questões dizem respeito à necessidade de estabelecer e hierarquizar os critérios de correção, bem como as formas de corrigir, e serão discutidas a seguir.

\subsubsection{Estabelecer e hierarquizar os critérios e a forma de correção: como e o que corrigir}

Este item trata de uma questão delicada e convém frisar que o que será discutido a seguir não pode nem deve ser tomado como regra, como a única ou a mais correta forma de corrigir um texto, embora se tenha mostrado um procedimento eficaz na correção de diferentes seqüências discursivas nesta e em outras pesquisas (cf. Guedes, 1998; Conceição 2000a; 2000b; 2002), especialmente por atender às expectativas dos alunos para resolver os problemas do texto, conforme indica o seguinte registro: À medida que a professora e os alunos faziam suas colocações, eu "visualizava" o que deveria mudar em meus textos (Diário do dia 21/09/01 - C 3).

\footnotetext{
12 Termo utilizado por Pécora (1992).

${ }^{13}$ Isso tem relação com o tipo de correção e será discutido a seguir.

${ }^{14}$ No item 3.1.2 serão analisados os comentários do professor ao texto do aluno.
} 
Quanto à correção de texto na escola, pesquisas têm apontado (Cf. Ruiz, 1998; Jesus, 2000; Brumatti, 1999) que a prioridade tem sido dada aos aspectos formais/gramaticais que aparecem na superfície textual, tais como ortografia, pontuação, concordância, acentuação, entre outros. E o resultado desse trabalho tem se mostrado desanimador aos professores e aos alunos. Para os professores, o desânimo está relacionado com o fato de que, à medida que os alunos avançam na escolarização, seus textos, além de perderem a qualidade (Cf. Pécora, 1992; Costa Val, 1993; Conceição, 2000a), vão encurtando de tal modo que escrever mais que dez linhas torna-se um suplício. Para os alunos, o exercício da escrita torna-se desanimador porque os comentários não atendem às expectativas que têm para resolver os problemas do seu texto (Cavalcante, Cohen, 1990).

Constatamos, neste trabalho, que o professor procurou centrar o foco de suas observações nos aspectos discursivos ${ }^{15} \mathrm{em}$ detrimento dos aspectos formais que, nas primeiras versões, foram ignorados. Esse procedimento parece ter levado o aluno a refletir primeiramente sobre seu discurso para, num momento posterior, preocupar-se com o polimento da superfície textual.

Para efetivação deste trabalho, dois procedimentos se mostraram determinantes: "como corrigir o texto" (tipo de correção usado) e "o que corrigir no texto" (priorização do problema a ser corrigido). Para encaminhar essa discussão tomaremos como referência o

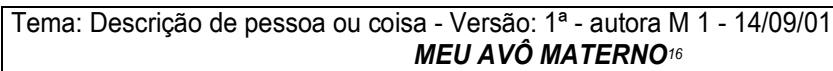

Numa pequena cidade do interior de Mato Grosso do Sul, o senhor José Moreira passou a maior parte de sua vida. Trabalhou na zona rural onde tinha um sítio.

(1)Relacionava-se muito bem com as pessoas da comunidade pois era muito humilde, bondoso e trabalhador.

Devido a (2)essas características foi um (3)ótimo pai de família, um excelente avô e uma pessoa muito agradável para com os amigos.

Meu avô não acumulou riquezas materiais durante sua vida,(4)mas foi rico em caráter, ética, dignidade e amor. E. (5) mesmo após sua morte em 1990, quando tinha 72 anos continua sendo um exemplo a ser seguido por sua família.

\section{COMENTÁRIOS ESCRITOS PELA PROFESSORA}

1) Obs. da professora ao primeiro trecho marcado: Faltam objetividade e concretude. Mostre os fatos, o restante o leitor conclui.

(2) Obs. Da professora ao segundo trecho marcado: Quais? (características) Você não mostrou nada ao leitor.

(3) Obs. da professora ao terceiro trecho marcado: Mostre fatos para que o leitor julgue isso. Como é esse personagem que, sendo um bom pai, um bom avô, foi um bom amigo?

(4) Obs. da professora ao quarto trecho marcado: O leitor só acredita no que pode "ver", "sentir", "cheirar"...

(5) Obs. da professora ao quinto trecho marcado: Como isso acontece? Mostre! Obs. geral da professora ao texto: Qual é questão deste texto? É preciso estabelecer um ponto de vista a partir do qual o leitor vai ser conduzido a apreciar este personagem, caso contrário, o leitor vai ficar perdido e a personagem retalhada.

\footnotetext{
${ }^{15}$ Aspectos Discursivos, neste trabalho, referem-se aos aspectos pragmático e semântico-conceitual do texto e, aspectos formais referem-se à gramática, à estrutura, aos aspectos aparentes na superfície textual.

${ }^{16}$ A versão reescrita deste texto está no anexo, no final deste trabalho. Embora ainda apresente problemas, ilustra os ganhos qualitativos do texto.
} 
exemplo do Quadro 1, escrito a pretexto do tema "descrição de pessoa ou coisa", no qual a professora fez sua correção e registrou seus comentários que foram aqui transcritos para análise.

Quanto ao tipo de correção utilizado, isto é, como corrigiu, os resultados desta investigação não apontaram nenhuma incidência de correção do tipo resolutiva; pelo contrário, da forma como foram feitas as correções, o professor devolveu a palavra ao aluno, além de desafiá-lo a pensar sobre seu discurso. Esse procedimento pressupõe uma opção por um tipo de correção menos mecânico e impessoal, mais dialógico e, portanto, polifônico. Verificamos que fez uso dos tipos textual-interativo conjugado ao indicativo $e$ ao classificatório. Isto é, houve uma indicação do problema (trechos foram sublinhados com vistas a apontar com certa precisão os locais em que julgou que o discurso se apresentava frágil) - correção indicativa; fez-se uma classificação do problema do ponto de vista discursivo ${ }^{17}$ - correção classificatória; e estabeleceu-se um diálogo (geralmente em forma de perguntas) através do qual o aluno foi desafiado a repensar o seu dizer - correção textual-interativa. Talvez o procedimento adotado, por ter atendido às expectativas dos alunos, possa ser uma das explicações para a intensidade ${ }^{18}$ e a qualidade ${ }^{19}$ das reescritas.

Quanto a "o que corrigiu", verificamos que a professora privilegiou os problemas discursivos. Teve como suporte para sua análise e observações as qualidades discursivas (Guedes, 2002), ignorando os problemas formais, nas primeiras versões.

Nas cinco observações escritas pela professora - Quadro 1 -, pode-se verificar que fez basicamente duas solicitações: "maiores informações" sobre o personagem descrito e que essas observações fossem "mostradas através de fatos". Tais observações correspondem à detecção da ausência das qualidades discursivas objetividade e concretude. A primeira postula que o leitor deve receber todas as informações necessárias no próprio texto, posto que texto escrito é uma interlocução à distância. A segunda postula que ao leitor cabe o direito de julgar os fatos por si próprio para tirar suas conclusões.

Desse modo, pode-se entender que o professor procurou explicitar em suas observações que é mais recomendável, nesse tipo de seqüência discursiva, descrever a cena ou as ações do personagem ao leitor do que lhe apresentar apenas a apreciação do autor, impedindo que o leitor julgue os fatos por si próprio, como fez a autora do texto exemplificado no Quadro 1, impedindo o diálogo do leitor com o texto e seu autor.

$\mathrm{Na}$ observação geral escrita pela professora, as indagações se dirigiram para a falta das qualidades discursivas unidade temática e questionamento. Isto é, o aluno foi desafiado a refletir sobre a necessidade de o texto se organizar em torno de uma questão de modo a se construir um sentido global para o texto (pressupõe-se que essa questão mobilize o leitor a dialogar com o texto concordando, discordando, desejando participar da construção dos sentidos), do contrário, como no exemplo citado e que trata de uma descrição de

${ }^{17}$ Estabeleceu-se como critério de análise da qualidade discursiva dos textos a presença das qualidades discursivas postuladas por Guedes (1998), detalhadas mais adiante.

${ }^{18}$ Em um mês e meio, para 4 temas, 11 alunos escreveram 133 textos (44 primeiras versões, 89 reescritas).

${ }^{19}$ No anexo 1, as mudanças qualitativas sofridas pelo texto (versão 1, Quadro 1), ainda em processo de reescrita, podem ser constatadas. Por falta de espaço, o texto do anexo 1 não foi analisado nem se pode apresentar outras versões. 
pessoa, a personagem descrita corre o risco de ficar retalhada e o leitor perdido em meio às informações soltas no texto.

Quando o leitor não consegue construir um sentido global para o texto, abandona a leitura antes mesmo do seu final. Isso corresponde ao fracasso do texto enquanto interlocução à distância.

Com o objetivo de explicitar um pouco mais o processo dialógico de correção efetivado, no Quadro 2 apresentaremos um outro texto da mesma aluna-autora. O texto foi escrito a propósito de um outro tema: "Relato de uma emoção forte".

Convém, antes, destacar um fato interessante que ocorreu quando a aluna recebeu a primeira versão desse texto com os comentários da professora e o leu para a sala analisar e fazer seus comentários. Após essa atividade, a aluna procurou a professora e perguntou se poderia escrever, a partir do mesmo tema, sobre um outro fato, sobre uma outra questão. A professora disse que sim e informou à autora que deveriam ser dela, e não da professora, a decisão e a responsabilidade sobre a questão a ser tratada. Acrescentou, ainda, que o leitor iria esperar dela e não da professora um texto interessante para $\operatorname{ler}^{20}$.

Que análise podemos fazer desse fato? Uma delas, a que pretendemos destacar aqui de maneira bem sucinta, tem relação com a autoria. $\mathrm{O}$ aluno em situação escolar geralmente não se preocupa com o leitor, nem mesmo assume a autoria do seu próprio texto e, portanto, não se sente na obrigação nem no direito de fazer mudanças substanciais, afinal, o que ele está acostumado a modificar nos seus textos são os aspectos aparentes na superfície textual. Como as indagações feitas pela professora (verificar a seguir Quadro 2) indicavam a necessidade de mudanças profundas, a aluna sentiu-se insegura. De um lado, havia um texto o qual percebera não estar funcionando junto ao leitor e, do outro lado, tinha a própria autora que, como tal, precisaria assumir as estratégias do seu dizer, mas conhecia suas limitações para tratar daquela questão de modo a atender as exigências do leitor. Considerando que, na escola, o aluno não assume a autoria do seu dizer, a atitude da professora-aluna foi a de procurar a professora para lhe pedir permissão para mudar a questão tratada no texto. A depender do encaminhamento da professora, mais uma vez teríamos a redação escolar se constituindo e não um autor tomando consciência de que ele precisaria decidir, fazer as escolhas sobre aquilo que pretendia dizer de modo a conquistar a atenção do leitor.

Neste caso, como o professor pretendia que seus alunos assumissem a autoria dos seus textos, devolveu ao aluno o direito de decidir sobre o que dizer a partir do tema proposto, mostrando-lhe a importância de se responsabilizar pelos rumos do seu texto, pelo sucesso (ou não) junto ao leitor. Postura contrária impediria a assunção à autoria, levaria à redação escolar.

Da mesma forma que no Quadro 1, apresentaremos e analisaremos a seguir a $1^{\text {a }}$ versão do texto da aluna e a correção feita pela professora.

${ }^{20} \mathrm{O}$ resultado da mudança, a $3^{\mathrm{a}}$ versão do texto escrito para o tema "relato de uma emoção forte", está no anexo 2, no final deste trabalho 
Tema: Relato de uma emoção forte20 - Versão: $1^{\text {a }}$ - autora M 1 - 14/09/01

\section{A ENTRADA PARA UNIVERSIDADE}

$O$ início de tudo foi a inscrição para o vestibular em 1992. (1) Preenchi o formulário meio insegura, pois havia um ano que tinha terminado 0 ensino médio e nesse período não havia feito cursinho. 0 Curso de Letras ainda era bem procurado, portanto não ia ser fácil.

(2) Tudo isso torturava-me e eu não conseguia pensar noutra coisa. Apesar de trabalhar oito horas por dia no comércio eu não me sentia cansada, tamanha era minha inquietação. Assim eu fazia leitura no horário de almoço, à noite, e aos domingos. $\mathrm{E}$, além disso, escrevia redações freqüentemente, o que eu mais desejava era ir bem no vestibular. (3) 0 medo que eu tinha de reprovar era imenso. Eu precisava entrar para a faculdade.

Assim passaram-se quase três meses. Eu, (4)com toda a ansiedade que pude ter, aguardava o comunicado sobre o local onde eu faria as provas que seriam divididas em duas etapas.

Quando a correspondência chegou eu soube. Seria na escola Presidente Vargas. (5)Comecei a me preparar ainda mais e a imaginar como seriam as provas.

0 grande dia chegou e lá estava eu com quase uma hora de antecedência. Quando entrei fui logo para a sala aguardar o início das provas que começaram às oito horas. Por incrível que pareça no momento da prova fiquei mais tranqüila. (5)Passei para a segunda etapa e agi da mesma maneira. Dessa forma conclui as provas e iniciei outro (6)momento de sofrimento aguardando 0 resultado.

Eu soube no meu local de trabalho, pelo rádio. (7)A minha felicidade foi tanta que todos percebiam. Eu não conseguia esconder. Eu havia conseguido o que mais queria naquele momento - ingressar numa universidade.

\section{COMENTÁRIOS ESCRITOS PELA PROFESSORA}

1) Obs. da professora ao primeiro trecho marcado: Como é a insegurança dessa personagem. Mostre isso ao leitor. Ele precisa "ver" a cena.

(2) Obs. Da professora ao segundo trecho marcado: Tudo isso o quê? Você não mostrou nada ao leitor.

(3) Obs. da professora ao terceiro trecho marcado: Mostre fatos para que o leitor julgue isso. Mostre como se passava esse medo no interior da personagem.

(4) Obs. da professora ao quarto trecho marcado: Como é a ansiedade dessa personagem? O leitor só acredita no que pode "ver", "sentir"... Ou melhor, o leitor quer sentir junto com a personagem.

(5) Obs. da professora ao quinto trecho marcado: Como aconteceu essa preparação? Mostre! 0 que essa personagem imaginava? Assim o leitor fica perdido

(6) Obs. da professora ao sexto trecho marcado: Mostre como foi esse sofrimento ao leitor. Não bastar afirmar, é preciso mostrar para que o leitor julgue os acontecimentos.

(7) Obs. da professora ao sétimo trecho marcado: Não se esqueça de que o leitor não estava lá no seu local de trabalho para ver os acontecimentos. Você precisa descrever como foi essa felicidade, como reagiu essa personagem para que o leitor possa também perceber.

Obs. geral da professora ao texto: 0 leitor quer o diferente, o inusitado. Aquilo que só a personagem do texto tenha vivenciado de seu modo particular. Essa situação, da forma como está aqui narrada, é comum a todos os que já fizeram um vestibular. 0 comum, o que todo mundo já sabe como foi não interessa ao leitor.

Qual é questão deste texto? Qual é o problema?

${ }^{21}$ Embora ainda apresente problemas, a $3^{\mathrm{a}}$ versão (anexo 2) ilustra os ganhos qualitativos do texto. 
Quanto ao tipo de correção utilizado, isto é, como corrigiu, podemos constatar que essas correções seguem o mesmo padrão do apresentado no Quadro 1: as correções desafiaram os alunos a pensarem sobre seu discurso devolvendo-lhes a palavra. Isso reforça a opção do professor por um tipo de correção menos mecânico e impessoal, mais dialógico e, portanto, polifônico.

Quanto a "o que corrigiu" verificamos que a professora, mais uma vez, privilegiou os problemas discursivos, ignorando os problemas formais na primeira versão. Nas sete observações escritas - Quadro 2 - fez basicamente três solicitações: a) "dar maiores informações" sobre as atitudes da personagem; b) "apresentar fatos que mostrassem" os acontecimentos ao leitor e; c) na observação geral, "problematizar melhor a questão" para o leitor.

Como se pode verificar, essas solicitações colocam o leitor no centro da preocupação do redator. Isso permite inferir que "o como fazer", o modelo, será determinado em função da interlocução desejada e não em função de um modelo preestabelecido que será apresentado pelo professor.

As observações feitas nos itens a) e b) são semelhantes às feitas no texto exposto no Quadro 1 e correspondem à detecção da ausência das qualidades discursivas objetividade e concretude. Essas solicitações parecem reforçar a insistência da professora em procurar explicitar, nas suas observações, a idéia de que é mais recomendável descrever a cena ou as ações do personagem ao leitor do que lhe apresentar apenas a apreciação do autor, impedindo que o leitor julgue os fatos por si próprio. Sem os dados no texto, o leitor fica impossibilitado de dialogar com as idéias e seu autor. Esse fato ocorre principalmente quando a história, sem assumir a perspectiva do escritor, confunde o discurso oral e o discurso escrito (Gallo, 1995). Escreve como se estivesse numa roda de bate-papo, contando um caso para um grupo de amigos, velhos conhecidos que já sabem parte da história, portanto, faz-se desnecessário contar certos detalhes que, se o ouvinte julgar imprescindível para a compreensão, perguntará.

Na observação geral escrita pela professora, item c), as indagações se dirigiram para a falta da qualidade discursiva questionamento. Essa solicitação revela uma preocupação em explicitar que não basta o autor apenas selecionar uma questão que julgue interessante para si próprio. Ele precisa tornar a questão interessante para o leitor e, para isso, é preciso problematizá-la, além de fornecer os elementos necessários para que o leitor possa entender e avaliar a história que está sendo contada. É isso que levará o leitor a se sentir enredado na teia da história, envolvido por ela, participando ativamente da construção dos sentidos.

De certo modo, o texto do Quadro 2 se organiza em torno de uma questão, tendo em vista que o próprio tema remete a isso: "Relato de UMA emoção forte". Esse tipo de observação feito pela professora parece ter o objetivo de levar o aluno a perceber que não basta apenas se preocupar em construir todo o texto em torno de uma questão, esta precisa ser interessante ao leitor. Nas palavras de Guedes (2002), essa forma de contar tudo muito vaga e genericamente faz parte da tradição da redação escolar. Segundo o autor, geralmente, quando o aluno se vê diante da necessidade de escrever um texto, não pensa no leitor; pensa apenas em desincumbir-se dele (do texto), livrar-se o mais rapidamente possível da tarefa (p. 119). Essa atitude tem subjacente a idéia de que, na escola, só se escreve para o professor e sobre aquilo que ele mandou, embora ele não esteja interessado em saber o que 
o aluno pensa ou diz. O resultado disso é a perda total da qualidade discursiva: um texto chato de ser lido, cansativo embora curtinho, sem graça e que só o professor de Português lê, quando se vê obrigado a atribuir uma nota de redação para cumprir uma burocracia do processo avaliativo escolar.

Em resumo, as qualidades discursivas aqui referidas, do ponto de vista pedagógico, correspondem a um conjunto de características que determinam a relação que o texto vai estabelecer com seus leitores por meio do diálogo que trava, não só diretamente com eles, mas também com os demais textos que o antecederam na história dessa relação (Guedes, 2002). Esse conjunto de características a que se refere o autor foi sistematizado nas quatro qualidades ${ }^{22}$ citadas e explicitadas na análise feita.

No que se refere ao uso dessas qualidades discursivas como critério de análise e de correção dos textos, parece que as mesmas foram determinantes na qualidade da interlocução estabelecida entre professor $\mathrm{x}$ texto $\mathrm{x}$ aluno. Elas direcionaram o olhar do professor (e dos alunos também) para o discurso. Em decorrência disso, propiciaram o inevitável diálogo com o texto e seu autor, resultando na constituição do professor-interlocutor.

\subsubsection{Negociar a forma de publicação do texto durante e após o processo de elaboração}

Ao se propor a ensinar a produzir textos é imprescindível que o professor negocie as formas de publicação. Esse procedimento leva o aluno-autor a assumir-se como sujeito do seu discurso, responsabilizando-se diante da audiência pelo seu dizer. Isso resulta em benefícios para o desempenho discursivo do aluno em sua produção escrita.

Verificamos a utilização, durante a fase de elaboração/refacção dos textos, do seguinte procedimento para publicação: após a primeira escrita de cada versão para o tema proposto, geralmente elaborada em casa, cada um fazia a leitura oral para a sala (combinou-se que, após a leitura, o autor não poderia dar explicações orais às dúvidas dos leitores; deveria reescrever o texto e reapresentá-lo), de modo que todos os colegas e o professor fossem considerados interlocutores. Convém esclarecer que essa leitura aqui referida não correspondeu àquela leitura privilegiada, somente da melhor redação escolhida pelo professor, sem explicitar quais critérios o levaram a tomar tal decisão. Correspondeu à leitura para publicação e para análise de todo e qualquer texto que tivesse sido produzido a partir de alguma solicitação feita em sala. Dessa maneira, o professor e os colegas, utilizando-se de critérios ${ }^{23}$ de análise previamente estabelecidos, comentavam o texto. Assim, a sala de aula consituiu-se no primeiro local em que o texto foi efetivamente publicado.

Essa estratégia revelou-se produtiva para desconstruir a prática - utilizada na maioria das salas de aula - de ler em sala somente o melhor texto do melhor aluno. Isso parece ter ocorrido devido ao fato de que todos foram colocados diante do direito de se sentirem o centro da atenção na sala de aula, o que resultou na obrigação de se posicionarem como sujeitos de seu dizer. Além disso, contribuiu para a construção do conceito de que texto é coisa pública e, sendo assim, não deve ser escrito de qualquer jeito nem deve o aluno

${ }^{22}$ Mais informações sobre as qualidades discursivas unidade temática, objetividade, concretude e questionamento conferir em Conceição (2000a, 2000b) e Guedes (2002).

${ }^{23}$ Neste trabalho, só para relembrar, foram levadas em conta as qualidades discursivas. 
pensar que somente o professor irá lê-lo, ou, talvez, nem ele, visto que o texto ficará guardado na gaveta servindo apenas como prova da tarefa cumprida.

Pelo menos três resultados decorrentes desse procedimento pudemos constatar. $\mathrm{O}$ primeiro correspondeu ao fato de que se providenciou um público leitor - os colegas de sala e o professor. O segundo correspondeu ao fato de que, ao analisar o texto, todos precisaram exercitar a explicitação de critérios de apreciação do texto dos colegas, estabelecendo comparação entre textos. O terceiro correspondeu ao fato de o autor ter sido levado a constituir-se num leitor mais crítico do próprio texto, já que se viu obrigado a considerar a existência do interlocutor durante o processo de elaboração do texto (neste primeiro momento, mais real do que virtual). Como se sabe, o interlocutor é quem determina/ influi, desde o processo inicial de elaboração de um texto, em “o que, para que, como" será dito o que se pretende dizer, naquele momento, para aqueles interlocutores.

Além disso, evidenciou-se que esse procedimento interativo democratizou a participação, tendo em vista que todos foram colocados na obrigação de ouvirem e no direito de serem ouvidos em sala de aula, de maneira que tal atitude pareceu contribuir de forma mais eqüitativa para com a busca do domínio da escrita por todos os alunos.

Procedimento inverso, aquele que privilegia a leitura e a divulgação apenas do melhor texto, do melhor aluno da sala, leva à privatização da língua representada pelo domínio de poucos, principalmente dos agraciados pelo talento. $\mathrm{O}$ resultado de um procedimento semelhante a esse é que todos os não-agraciados pelo talento - e é sempre a maioria absoluta - acabam convencidos pela escola de que escrever é privilégio de poucos iluminados. Talvez essa seja uma estratégia do "inconsciente escolar" que tem funcionado durante anos, já que, ao convencer os que procuram a escola de que não têm talento para a escrita, esta se exime da culpa de não conseguir ensinar a escrever a quem, ironicamente, entrou na escola para aprender a escrever.

Os depoimentos abaixo, retirados do diário de aula, indicam que esse procedimento didático da leitura oral do texto em elaboração, apesar de causar constrangimentos no início, resultou muito eficaz e, não fossem as reflexões registradas nos diários de aula escritos pelos alunos, provavelmente não se teria como constatar os seus efeitos na (re)construção do conhecimento dos alunos sobre a produção escrita:

Passamos à leitura dos textos. [...] à medida que lia, conseguia já perceber onde estavam meus erros, e o que faria para melhorar o texto, deixá-lo interessante, atraente. Era incrível, como eu podia ter deixado de lado fatos tão interessantes. [...] A sala fez as observações exatamente em cima dos pontos que eu já conseguia observar. Foi muito, muito bom. Eu queria escrever (Diário do dia 22/09/01 - C 4).

...pois ao ler os textos fomos percebendo a necessidade de reescrevê-los e a preocupação que deveríamos ter tido com o interlocutor, preocupação essa que foi esquecida no momento da produção textual (Diário do dia 17/09/02 - J 1).

$\{\ldots\}$ Eu estava ansiosa para ouvir a leitura dos textos dos colegas e também dos meus. Aquele era para mim o momento real do aprendizado (Diário do dia 28/09/01 - C 4).

Em uma fase posterior ao processo de elaboração/reelaboração em situação escolar, o texto pode/deve ser publicado em sua edição final em diferentes veículos tais como 
jornal mural, livro de textos, jornal escolar, varal, festas escolares, entre outros. Nessa fase de publicação, um novo tipo de leitor passa a ser considerado: o leitor virtual, isto é, aquele que o autor pode/deve pressupor já que não terá acesso real a ele - assim como teve aos colegas de sala e ao professor, quando o texto ainda estava em processo de elaboração -, por isso mesmo deve prever, antecipadamente, as possíveis dúvidas e indagações do seu leitor.

Um dos efeitos da prática de leitura do texto em sua fase de elaboração foi o fato de ter levado os alunos a sentirem necessidade de reescrever seu texto a partir das intervenções dos interlocutores para poder reapresentá-lo para a audiência. Como se vê, esse procedimento toca na questão da reescrita, a ser discutida a seguir.

\subsubsection{Possibilitar a reescrita quantas vezes o autor do texto julgar necessário.}

No diário das primeiras aulas...

$\{\ldots\}$ Todos leram em voz alta, ao chegar a minha vez, achei minha redação sem graça que quase não consegui ler. Mas, para piorar a situação, a professora solicitou a reescrita. Detesto refazer e, em se tratando de escrita, é pior ainda, me sinto sob tortura (Diário do dia 15/09/01 - T 9).

E, como sempre tive o conceito que escrever bem não significa reescrever, [...] quando pediu para eu reescrever o texto eu disse que se eu pegasse o texto não o devolveria mais porque a palavra refazer e reescrever estavam fora do meu vocabulário (Diário do dia 22/09/01 - T 9).

No diário do último encontro...

Comecei a fazer esta disciplina convicta de que para escrever bem não era necessário reescrever, pois refazer para mim significava "desmanchar" o texto. Só depois que entendi o significado de reescrever, visto aqui como melhorar a qualidade do texto, é que consegui refazer sem culpa e medo de estragar o texto. Dessa forma, esta aula não teve para mim o significado "tortuoso" do início da matéria mas sim o sentido de aprender (Diário do dia 29/09/01 - T 9).

Esses registros são reflexões da mesma professora-aluna em diferentes momentos: os dois primeiros, nas primeiras aulas; o terceiro registro ${ }^{24}$ corresponde ao último diário em que a aluna refletiu sobre os conflitos vividos e sobre sua possível mudança de postura frente à reescrita.

Esses registros permitem pelo menos duas constatações sobre o conceito de escrita/ reescrita: a primeira delas corresponde ao fato de que, geralmente, a reescrita não é vista, nem mesmo pelos professores, como parte do processo de produção textual. Em conseqüência disso, o que se pratica no ensino de produção textual em geral nas escolas é que a primeira versão é considerada a versão definitiva. Falar em reescrita é falar em perder tempo. Aliás, geralmente, não se fala em reescrita. E, a segunda constatação é que reescrever o texto não é visto como oportunidade de melhorar sua qualidade discursiva, mas como um castigo, um desrespeito a quem, após muito trabalho, produziu algumas

\footnotetext{
${ }^{24}$ Convém esclarecer que não houve nenhum tipo de direcionamento sobre as questões que poderiam ser objeto de reflexão nos diários. A decisão sobre o que refletir era feita unicamente pelo aluno.
} 
sofridas linhas. Estas eram crenças que precisaram ser desconstruídas para que o trabalho fluísse.

Neste trabalho, a primeira versão nunca recebia qualquer conceito avaliativo. A partir da segunda versão, no entanto, o grupo de professores (como em qualquer contexto escolar) solicitou que, além das observações, fosse feita uma avaliação que lhes desse um parâmetro da evolução qualitativa dos textos. Estabeleceu-se que o conceito D seria dado ao texto, após a primeira reescrita, que não tivesse atingido minimamente as qualidades previstas; o conceito $\mathrm{C}$ seria dado ao texto que apresentasse parcialmente as qualidades previstas e o conceito B corresponderia ao que tivesse atingido satisfatoriamente as qualidades discursivas. O conceito A seria dado ao conjunto das produções que, tendo sido reescritas quantas vezes seu autor julgasse necessário, atingisse uma boa qualidade discursiva e não apresentasse problemas na superfície textual. Isto significa que, após a recuperação do discurso, quando o texto é dado por pronto e será editado, deve-se exigir o cuidado com a forma.

Uma das descobertas que parece terem feito foi a de que, sem o direito de reescrever quantas vezes julgassem necessário (procedimento que, geralmente, é adotado em sala de aula em que a primeira versão é a versão definitiva), seus textos dificilmente atingiriam a qualidade que atingiram. O trecho seguinte mostra isso com clareza: Estou desesperada. Não consigo sair do D e meus textos continuam apresentando os mesmos problemas. Se houver prazo vou ficar produzindo esses textos até o final do ano e vou ter que aprender (Diário de aula 29/09/01 - I 2). Parece terem descoberto também que, às vezes, são necessárias inúmeras reescritas para que o texto atinja sua principal meta: prender a atenção do leitor, levando-o a reagir ao texto de modo a concordar, discordar, dialogar, enfim, com o texto e seu autor, livrando-se, com isso, da "forma" em que é colocado durante o processo de escolarização. Os trechos seguintes evidenciam o quanto é forte essa idéia: Acredito que ainda estamos com a idéia fixa de que o texto está bom da forma como o escrevemos e aprendemos no decorrer de nossa vida escolar (Diário do dia 29/09/01 - E 1).

\footnotetext{
Nesta segunda-feira, a aula foi muito divertida, afinal, nós, professores, passamos por uma situação engraçada: escrevemos tão infantilmente que se nossos alunos lessem nosso texto não acreditariam que o seu professor produz um modelo igual ao de qualquer aluno do ensino básico (Diário do dia 17/09/01 - T 9).
}

\section{CONSIDERAÇÕES FINAIS}

Fazendo uma apreciação geral sobre o trabalho desenvolvido, concluímos que os procedimentos adotados - o processo interlocutivo instaurado entre professor x aluno; o estabelecimento e a hierarquização dos critérios de correção; a publicação dos textos, especialmente durante o processo de elaboração e a reescrita constante e reiteradas vezes do próprio texto - possibilitaram aos professores-alunos uma reflexão sobre a teoria e a prática no que se refere às ações docentes na condução do processo de ensino de produção textual, além de lhes permitir vivenciar as angústias, as inseguranças, as dúvidas que os alunos vivenciam e o professor, geralmente, não faz a mínima idéia, por acreditar que a 
linguagem é homogênea, transparente, unívoca, linear e, portanto, despida de qualquer ambigüidade ou indeterminação.

Essa reflexão, que durante um certo período pareceu ter sido rejeitada pelos professores-alunos que buscavam receitas prontas sobre as questões que os afligiam na sua prática - Como corrigir? O que corrigir? Para quê corrigir? -, foi sendo problematizada de tal forma que, no decorrer do processo, à medida que o vivenciavam, foram se colocando como sujeitos do processo em vez de se sentirem apenas na condição de apreciadores críticos de um processo que lhes tivesse sendo apresentado para julgarem.

No que se refere ao procedimento que diz respeito ao estabelecimento da interlocução, os registros aqui apresentados elucidam que o professor é realmente uma peça importante no jogo discursivo de sala de aula. Se este tomar a iniciativa de se colocar na posição de leitor, de interlocutor interessado em dialogar com o texto e seu autor, o aluno passa a assumir-se como sujeito do seu dizer e a fórmula da redação escolar passa a ser questionada, desconstruída.

No que tange ao estabelecimento e à hierarquização dos critérios e da forma de correção, a opção por priorizar os aspectos discursivos em detrimento dos formais, que foram propositalmente deixados de lado num primeiro momento da correção, resultou no desvio da atenção antes acostumada a olhar para os "erros" gramaticais, direcionando-a para o discurso. Quando o olhar, tanto do professor quanto do aluno, passou a desviar-se dos aspectos formais, a correção feita pelo professor e a revisão elaborada pelo aluno centraram-se no discurso. Desse modo, podemos concluir que um procedimento de correção que privilegie uma correção polifônica, isto é, que não silencie o dizer do aluno - tal qual a correção textual-interativa, conjugada à indicativa e à classificatória, centrada nos aspectos discursivos do texto - tende a ser bastante produtiva.

No que se refere à publicação através da leitura oral do texto para a sala - sem que se pudesse dar explicações além das existentes no texto escrito -, durante o processo de elaboração e reelaboração, esse procedimento parece ter possibilitado ao aluno refletir sobre o conceito de texto como interlocução à distância e, com isso, compreender parte das diferenças entre um texto oral (interlocução face-a-face) e um texto escrito (interlocução à distância), conceito extremamente complexo de ser construído pelos alunos em geral. Em resumo, pode-se afirmar que o procedimento de estabelecer com os alunos as formas de publicação do texto desde o momento inicial de sua elaboração, garantindo com isso a existência de interlocutores, correspondeu, na verdade, ao trabalho necessário de explicitação de parte de um dos aspectos mais importantes do processo de ensino de produção textual, as condições de produção, que influenciam de forma determinante na qualidade do texto a ser produzido.

No que concerne à reescrita, pode-se dizer que, do modo como foi trabalhada - como parte do processo de escrita de qualquer texto, orientada segundo critérios que priorizaram a qualidade discursiva em vez dos aspectos superficiais, valorizada e incentivada pelo professor e aceita e praticada pelo aluno -, torna possível vislumbrar um futuro muito mais promissor para o ensino-aprendizagem de produção textual, tendo em vista que a reescrita deixa de ser um problema para ser vista como um desafio, uma necessidade que faz parte do processo de escrita de qualquer texto que pretenda cumprir sua função interlocutiva: 
obter sucesso junto ao leitor, provocando-lhe algum tipo de reação que não seja a total indiferença.

Finalizando, pode-se dizer que as ações adotadas durante o trabalho de formação de professores em serviço - a experiência de serem colocados no lugar do "sujeito que faz", em vez de apenas refletirem sobre "o que os outros fazem" e o fato de poderem dizer e se dizer em seus textos - pareceu ser uma experiência inédita para aquele grupo e parece ter resultado muito proveitosa, embora no início tivessem reagido de forma arredia e questionadora às atividades propostas, fato que não parece ser comum nas salas de aula. As cenas gravadas em vídeo denunciam que, em alguns momentos, protestaram contra as reescritas, calaram-se quando podiam falar, riram nervosamente, recusaram-se a ler os textos. Tais reações evidenciam que, nas primeiras aulas, sentiram-se constrangidos e fragilizados em sua autoridade de professores detentores do conhecimento; afinal, estavam (como professores que eram) experimentando a incômoda posição de não-controle da situação e de si próprios. Para Coracini (2000), tal reação pode ser explicada pelo fato de que se parte do pressuposto segundo o qual, na cultura ocidental em que se inserem pesquisadores e pesquisados - , o diferente gera conflitos, as contradições são sinais de incoerência e, como tal, são objeto de repúdio. Por isso, é preciso afastar, abafar, apagar da consciência esses momentos que são freqüentemente vistos e analisados negativamente como deslizes, lapsos, manifestações do não controle da situação, de si e dos outros.

Convém ressalvar, ainda, que uma das limitações deste estudo consiste no fato de se pensar que, após sua conclusão, os participantes vão mudar completamente, como se as mudanças dependessem sobretudo do aspecto cognitivo do sujeito, e os demais aspectos, o afetivo, o sócio-histórico, o cultural, entre outros, pudessem ser desconsiderados em nome do sucesso da pedagogia desejada. Acreditamos, contudo, que este estudo tenha extrapolado, pelo menos em parte, o âmbito do cognitivo, tendo levado os participantes a se envolverem de maneira mais completa e complexa com o trabalho e, nesse sentido, apontou para outras questões que podem ser objeto de pesquisa no campo do ensino da produção escrita.

Mesmo tendo consciência dessa limitação, a ilusão, até certo ponto, de que as coisas vão mudar para melhor é condição necessária, já que corresponde a uma espécie de combustível que leva pesquisadores e pesquisados a não desanimarem, a buscarem soluções para os problemas frente aos quais se deparam, o que permite a eterna busca, em vez do desânimo e do conformismo causados pelas inúmeras frustrações das soluções sempre inacabadas, tão comuns (e por que não dizer inerentes à?) na educação.

\section{REFERÊNCIAS BIBLIOGRÁFICAS}

BAKHTIN, M. (1995). Marxismo e filosofia da linguagem. 7ed. São Paulo: Hucitec.

BRUMATTI, S. A. V. (1999). A correção de textos em escolas. Dourados: Monografia do Curso de Especialização em Língua Portuguesa da UFMS/DCO. 
CAVALCANTE, M. C. COHEN, A. D. (1990). Comentários em composições: uma comparação dos pontos de vista do professor e do aluno. Campinas: UNICAMP/IEL Setor de Publicações, Trabalhos em Lingüística Aplicada, V. 15, p. 7-23, jan/jun.

CONCEIÇÃO, R. I. S. (2000a). Da redação escolar ao discurso: um caminho a reconstruir. Pelotas: EDUCAT, Linguagem \& Ensino, v. 3, n. 2, p.109 - 133, julho.

(2000b). A reconstrução da discursividade na escrita: da redação escolar ao discurso. LEFFA, V. J. (Compilador). TELA (Trabalhos em L. Aplicada) [CD-ROM]. Pelotas: Educat.

. (2002). O ensino de produção textual e a (re)construção da competência discursiva do aluno. Trabalhos em Lingüística Aplicada. Campinas: UNICAMP/IEL, v.40, p. 45-62.

CORACINI, M. J. R. F. (1999). A redação no livro didático e na sala de aula: criatividade e avaliação. In. Interpretação, autoria e legitimação do livro didático Coracini, M. J. R. F. (Org.). Campinas: Pontes. p.153-158.

(2000). A teoria e a prática: a questão da diferença no discurso sobre e da sala de aula. Delta, v.14, n.1, 1998. In LEFFA, V. J. (Compilador). TELA (Trabalhos em Lingüística Aplicada). Pelotas: Educat. 1 CD-ROM.

COSTA VAL, M. da G. (1993). Redação e textualidade. São Paulo: M. Fontes.

GALLO, S. L.. (1995) Discurso da escrita e ensino. Campinas: Editora da UNICAMP.

GUEDES, P. C. (1998). Manual de Redação. Porto Alegre: FABICO/UFRGS. (2002). Da redação ao texto: um manual de redação. Porto Alegre: Editora da UFRGS.

JESUS, C. A. de. (1998). Reescrevendo o texto: a higienização da escrita. In Aprender e ensinar com textos. Chiappini, L. (Org.), São Paulo: Cortez.

PÉCORA, A. (1992) Problemas de redação. São Paulo: Martins Fontes.

RUIZ, E. M ${ }^{a}$ S. D. (1998). Como se Corrige redação na escola. 1998. 2 v. Tese (doutorado em Lingüística Aplicada). Instituto de Estudos da Linguagem, UNICAMP, Campinas.

SECRETARIA DE EDUCAÇÃO FUndAMENTAL. (1997). Parâmetros Curriculares Nacionais: Língua Portuguesa. Brasília: SEF.

SERAFINI, M. T. (1994). Como escrever textos. 6ed. São Paulo: Globo. 


\section{ANEXO 1}

TEMA: Descrição de pessoa ou coisa - $4^{\mathrm{a}}$ versão - autora: M 1 - 2001

\section{UM HOMEM SOCIÁVEL}

Bater papo era a atividade preferida de meu avô materno. Gostava de conversar sobre tudo o que envolvia sua comunidade.

Como morava num sítio no município de Glória de Dourados, em uma cidade pequena em relação a Dourados, os assuntos preferidos eram a agricultura, a política, a situação econômica e as festas religiosas que aconteciam por ali.

Os locais preferidos para bater papo eram as casas dos amigos para onde ia quase todas as noites. Um dia na casa do Sr. Manoel, outro na casa do Sr. Nilton, outro no Sr. Vicente. Era uma via sacra.

Acontecia assim: ele chegava da roça, guardava a enxada, o rastelo e os balaios que eram utilizados na lida com a lavoura. Tudo ele colocava no paiol velho de madeira que ficava a 50 metros da casa, ao lado do curral. Como era uma pessoa extremamente organizada, ele só tomava seu banho depois de organizar todas as ferramentas. Tomava banho, vestia-se, encilhava o cavalo cuidadosamente, montava e saía galopando na estrada. De longe ouvia-se só o barulho das patas do cavalo. Esse ritual repetia-se todos os dias da semana, cada dia na casa de um dos amigos.

Quando terminava de ir na casa de todos, ele recomeçava as visitas sempre com o objetivo de colocar as conversas em dia.

Se as conversas com os amigos eram ótimas, com os netos eram melhores ainda.

Aos sábados à tarde íamos eu e meus irmãos para casa de nosso avô. Ele chegava da roça mais cedo, tomava um suco de limão, era seu hábito, e nos chamava para que fôssemos para a sombra da mangueira que era um dos lugares mais aconchegantes do sítio. Segundo ele, aquela sombra era ótima para nós. Lá sentávamos na areia que era fresca e ele sentavase num banco de madeira que ficava ali. Em seguida começava a nos contar as mais belas histórias, aquelas que papai e mamãe não tinham tempo de nos contar.

Falava do Curupira, do Saci Pererê, da Cuca Malvada, do Lobisomem. Foi assim que começamos a conhecer as histórias populares. Nós pedíamos que ele nos contasse mais, mais...

Mas enquanto isso, o sol ia se pondo, deixando o horizonte alaranjado, a noite começava a cair. Era hora do Sr. José sair para conversar com os amigos. Agora era assunto de gente grande. 


\section{ANEXO 2}

TEMA: Relato de uma emoção forte - $3^{\mathrm{a}}$ versão - autora: M 1 - 2001

\section{CIDADE GRANDE}

Nasci num sítio, próximo ao município de Glória de Dourados. Eu e meus pais íamos até Glória todos os meses para fazermos compras, visitas e vendermos as mercadorias produzidas no sítio.

Meu universo restringia-se ao lugar onde morava: o sítio, onde eu conhecia todo mundo e a pequena cidade que sempre visitava.

Numa certa ocasião, minha mãe ficou doente e meu pai, muito preocupado, levou-a ao médico em Glória de Dourados mesmo. Depois de examiná-la superficialmente, o médico solicitou exames mais detalhados, pois desconfiava de algo mais sério. Esse exame não poderia ser feito na cidadezinha já que lá não tinha aparelho de raio $\mathrm{X}$.

Assim, fiquei sabendo por minha mãe que faríamos uma viagem. Iríamos para Dourados. Uma cidade maior e bem mais equipada, onde ela poderia fazer os exames.

Naquela noite não consegui dormir de tanta expectativa, estava muito contente. Saímos no outro dia bem cedinho de ônibus. Chegando em Dourados, a primeira impressão foi muito boa: vi vários carros circulando pela rua. Na praça tinha uma piscina com animais e até uma fonte luminosa.

Minha mãe falou para eu não "desgrudar" da mão dela, pois Dourados era uma cidade muito perigosa e eu não conhecia nada, nem ninguém.

Nos dirigimos ao local onde seriam feitos os exames. Uma moça muito bonita, loira e bem alta atendeu minha mãe e nos mandou aguardar sentados.

Logo minha mãe foi chamada e disse para eu ficar ali sentadinha, esperando por ela. Mas eu queria mesmo era olhar a rua apesar de ter muito medo, pois como minha mãe havia dito que Dourados era grande e muito perigosa. Olhava tudo em volta encantada. Mas pelo pedacinho da janela, podia ver a rua. Parecia que ela me chamava.

A recepcionista, lendo uma revista, nem me olhava, mas... minha mãe tinha mandado ficar ali sentada.

Pensei numa maneira de ver tudo lá de fora sem desobedecer minha mãe, não encontrei nenhuma. Devagarinho, me levantei. Um pé, depois outro, outro e... estava na rua. Nesse momento lembrei de tudo que tinha ouvido sobre como andar em cidades grandes e esse tudo se resumia a andar na calçada.

Resolvi ir até a esquina para ver o que tinha na outra rua. Chegando lá fui mais adiante e mais adiante. Olhava tudo e queria ver mais: casas lindas, jardins verdes, lojas com roupas erguidas nas portas. Nem percebi o tempo passar, somente quando um carro buzinou para mim, percebi que estava no meio da rua. Carros passavam de um lado e de outro rapidamente. Da mesma forma passavam motos, bicicletas, tudo e eu ali parada. Lembrei-me de minha mãe. Ela ficaria muito brava se soubesse da minha escapadinha.

Pensei em voltar depressa, entrar, sentar e ela nem notaria. Mas, voltar como? Não sabia mais onde era o laboratório de onde tinha saído. Estava perdida. Meu coração disparou, minhas pernas começaram a tremer e as lágrimas caíam sem que eu conseguisse segurar. 
Andava para todos os lados, pensava que era por um caminho, por outro e... nada. O desespero foi aumentando e eu nem mesmo conseguia enxergar direito. Olhava para as pessoas já só via pernas e mais pernas. Olhava para cima via prédios tão enormes para meus olhos de criança. Pensava na minha mãe e tinha medo de nunca mais vê-la. Chorava sem parar.

Um senhor me perguntou: "Ei, garota, cadê sua mãe? Lembrei-me de novo de minha mãe e de ouvir ela dizendo que não era para conversar com estranhos. Saí correndo mas o homem correu atrás gritando e pedindo para eu parar.

Corri tanto que não percebi o meio-fio e tropecei nele. Caí estatelada no chão. $\mathrm{O}$ homem me alcançou e perguntou se eu não era a menininha de Glória de Dourados que ele tinha visto a mãe procurando.

Respondi que sim, que tinha fugido do lugar onde ela estava e havia me perdido. $O$ homem me ajudou a levantar e me levou até minha mãe que, quando me viu, me abraçou tão forte, que quase me machucou e nem se lembrou de brigar comigo. 